\title{
FUNDAÇÃO: EVOLUÇÃO, CONCEITO E CARACTERÍSTICAS
}

\author{
Eugênio Carlos Callioli \\ Aluno de Doutoramento dos Cursos de Pós-Graduação, Área de Direito Civil, \\ sob orientação do Professor Doutor Walter de Moraes. Advogado em São Paulo
}

\begin{abstract}
Resumo: Ainda hoje, o conceito e disciplina jurídica do instituto das Fundaçōes apresentam profundas divergências doutrinárias. Esta monografia restringir-se-á a consideraçōes conceituais e históricas de ordem acadêmica e teórica. Com uma rápida passagem pelo histórico das Fundaçōes, pretende-se chegar a um conceito abrangente, que possa identificar suas características e seus elementos constitutivos. Por fim, são acrescentados breves comentários sobre alguns aspectos conflitivos na identificação de certas Fundaçōes (Fundação Pública, Fundações dotadas de patrimônio público), bem como as espécies que nos apresenta o atual projeto de Código Civil.
\end{abstract}

Summary: Even today, the concept and juridical discipline of the institution of Foundations presents profound doctrinary divergencies. This monography shall limit itself to conceptual and historical considerations from academic and theoretic standpoint. Starting with a rapid passage through the historical aspects of Foundations, an attempt is made in order to reach a general concept, that can allow one to identify its characteristics and constitutive elements. Finally, brief comments about conflicting aspects in the identification of certain Foundations (Public Foundations, Foundations with public patrimony), as well as types which are presented by the current Civil Code project are added.

Unitermos: Dados Históricos; Evolução; Conceito; Outras Características; As Fundações no Projeto de Código Civil.

FUNDAÇĀO: EVOLUÇĀO, CONCEITO E CARACTERÍSTICAS A Fundaçāo apresenta, ainda hoje, divergências profundas no referente a seu conceito e disciplina. Nas linhas desta breve monografia, trataremos tão-somente de aspectos históricos e conceituais do instituto, motivo pelo qual se restringirá às considerações de ordem acadêmica. Nāo desceremos, portanto, a aspectos mais práticos, bem como deixaremos para outra oportunidade o estudo aprofundado de outros elementos de sua conceituação (estatutos, os bens que podem ser elencados no patrimônio afetado, etc.).

Como é sabido, ao lado das associaçōes e das sociedades, o art. 16 do Código Civil brasileiro incluiu, entre as pessoas jurídicas de direito privado, as "Fundações". Assim procedendo, o Legislador pátrio - nas pegadas do germâ- 
nico - pôs termo a uma séria controvérsia, como nos esclarece o Prof. Silvio Rodrigues. Em linhas gerais, a Fundação é uma organização que gira em torno de um patrimônio que se destina a determinada finalidade a que a lei - cumpridos certos requisitos - atribui a capacidade para ser titular de direitos ${ }^{(1)}$.

\section{I - DADOS HISTÓRICOS. EVOLUÇÃO}

\section{1 - Origens}

As origens da fundação podem ser explicadas pelo espírito de solidariedade, apanágio do ser humano, presidindo a uma procura de meios de auxiliar as pessoas necessitadas.

Com efeito, desde os primórdios da história da humanidade, registram-se atitudes de homens que, movidos pelo amor às artes e à sabedoria ou o singelo amor ao próximo, legavam bens para alguma finalidade cultural e filantrópica.

Além da doação da biblioteca de Alexandria, pelos Ptolomeus, como as características, ao que consta, de patrimônio desligado da pessoa de seus proprietários, o exemplo mais notável de instituição precursora parece ter sido, no mundo antigo, a escola que Platão fundou nos jardins de Academos, a Academia; não era esta, propriamente, uma instituição de ensino, no sentido moderno, mas espécie de sociedade científica e religiosa consagrada às musas, em Atenas. Após tê-la dirigido durante cerca de vinte anos, legou-a o filósofo aos seus sucessores.

\section{2 - Direito Romano}

Vandick Londres da Nóbrega destaca a acentuada influência grega na formação das fundações do mundo romano, pois o século $\mathrm{V}$ a.C. presencia o surgimento das primeiras instituições assemelhadas, no mundo grego, destinadas ao culto dos deuses: quando a Grécia tornou-se província romana, os conquistadores assimilaram a instituição, pois, conforme ainda Londres da Nóbrega, é significativo que, após a conquista, tenham aparecido em Roma as primeiras fundações, dedicadas ao culto funerário, à distribuição de alimentos, à manutenção de crianças pobres e aos jogos ${ }^{(2)}$.

O direito romano, embora atribuísse personalidade jurídica somente aos entes do tipo associativo, concebia a existência de patrimônios, vinculados a determinados fins; à época do direito romano clássico não existiam patrimônios

(1) Cfr. Rodrigues, Silvio, Direito civil, Parte Geral, vol. I, Saraiva, São Paulo, 1974, 5 ed., pág. 70.

(2) Cfr. Nóbrega, Vandick L., História e sistema do direito privado romano, 3a ed., Rio de Janeiro, Freitas Bastos, pág. 136. 
dotados de autonomia jurídica que pudessem ser considerados antecedentes diretos da fundação, mas a solução preconizada consistia na transferência do patrimônio a uma cidade ou collegium, com a imposição dos fins de utilidade pública, o que era feito mediante testamento ou por ato inter vivos.

Os particulares não podiam constituir fundaçōes com os próprios bens, mas podiam doá-los ou legá-los a uma pessoa jurídica, com a estipulação do modus. O patrimônio "passava, então, à propriedade do donatário ou legatário, que se obrigava ao cumprimento dos encargos, com as rendas provenientes do objeto da doação ou legado, sob pena de multa (stipulatio poenae), ou de perda dos bens em favor de outra pessoa jurídica. Segundo Iglesias, tratava-se de autêntica fundação fiduciária",(3)

Nos primeiros tempos do Império, as fundaçōes alimentares parecem ter sido mero instrumento da ação do Imperador, não possuindo autonomia patrimonial ${ }^{(4)}$; entretanto, eram consideradas parte independente dos bens do Estado; o Imperador Trajano emprestou dinheiro a proprietários da regiāo de Valéia, e destinou os juros à manutenção de trezentas crianças pobres. Plínio, o jovem, fez doação de uma escola à cidade de Como.

Parece, pois, e trata-se de opinião uniforme "que os fundos especiais para a distribuição de alimentos foram os antecedentes mais parecidos com as modernas fundações, devido à finalidade característica e o grau de autonomia patrimonial desses fundos, sem, todavia, chegarem a ser personalizados (B. Eliachevitch, La personalité en droit privé romain, Paris, 1942, pág. 327 e $341)^{\prime \prime(5)}$.

A inexistência de patrimônios juridicamente personalizados no direito romano clássico é explicada, de um lado, por não terem os romanos elaborado uma teoria das pessoas jurídicas; espírito eminentemente prático, desenvolviam suas instituiçōes e as aperfeiçoavam na medida das necessidades da vida, sem a preocupação de justificativas filosóficas ou teorético-científicas, o que surgiu em momento posterior da evolução do direito positivo, com a necessidade de sistematizar e precisar o significado de conceitos incorporados à técnica jurídica; este momento, mais ou menos difuso na época de Justiniano, assinala o ponto de partida do direito como ciência; de outro lado, o próprio sentido prático do direito positivo de Roma explica o fato de não terem os romanos conce-

(3) Coelho, Luiz Fernando, Fundações Públicas, 1ª ed., Rio de Janeiro, Forense, 1978, pág. 9.

(4) Correa de Oliveira, José Lamartine, Conceito de pessoa jurídica, Curitiba, 1962, pág. 16.

(5) Eliachevitch, B., La personalité en droit privé romain, Paris, 1942, pág. 327 e 341; apud Coelho, Luiz Fernando, o.c., pág. 10. 
bido a personalidade jurídica das universitates rerum, uma vez que os objetivos de utilidade pública eram alcançados da mesma forma; de resto, com exceção da personalidade, todas as características das modernas fundações podem ser encontradas nas fundaçōes fiduciárias romanas, inclusive a vigilância do Estado, por meio do curator reipublicae, instituição desenvolvida no segundo século com o aperfeiçoamento do organismo administrativo romano; a similitude com as modernas fundações é tal que, a propósito das fundações alimentares imperiais, sustentou Brintz tratarem-se de autênticas fundaçōes no sentido do direito moderno ${ }^{(6)}$.

O mesmo autor refere-se aos templos e bens dedicados ao culto dos deuses, afirmando tratarem-se de verdadeiros patrimônios autônomos. Semelhante opinião, todavia, não encontra guarida e é refutada, entre outros, por Ferrara ${ }^{(7)}$.

\section{3 - Surgimento do instituto}

$\mathrm{Na}$ história das fundações, dois acontecimentos assumem especial relevância: o primeiro é a constituição de uma actio popularis com o fim de serem efetivadas as fundações instituídas por legado ou doação; o segundo relacionase com o desenvolvimento das entidades religiosas, em especial a concepção da Igreja como pessoa.

Observa Jhering que as fundações "são por si mesmas o objeto e centro de gravidade de todas as rodas jurídicas que as fazem mover, mas o eixo do seu mecanismo está nas pessoas naturais, que são as que se devem dela aproveitar. A personificaçāo das fundações é, pois, a forma apropriada de um patrimônio servir aos interesses e aos fins de pessoas indeterminadas", ${ }^{,(8)}$.

A partir da constituição da actio popularis, no direito novo, configura-se para Jhering um direito subjetivo dos destinatários da fundação: pobres, enfermos, viúvas, órfãos, protetores das artes, etc., "porque os dois elementos do direito, o interesse e a proteção do interesse por si mesmo, se encontram efetivamente nela"(9).

(6) Apud Ferrara, Francesco, Teoria de las personas jurídicas, trad. Eduardo Ovejero y Mauri, Madrid, Ed. Reus, 1929, pág. 37.

(7) Ferrara, Francesco, o.c., pág. 37.

(8) Jhering, R., O espírito do direito romano, trad. Rafael Benaion, Rio de Janeiro, Ed. Alba, 1943, v. 4, pág. 230.

(9) Jhering, r., o.c., pág. 231-232. 


\section{4 - Instituições eclesiásticas. O Cristianismo}

Com o desenvolvimento das instituiçōes eclesiásticas fundadas na Igreja como corpus mysticum, entidade mística e impalpável, passaram a ser conhecidas como entes distintos aquelas instituiçōes de benemerência e culto, organizadas em torno das igrejas e conventos; com efeito, o pium corpus, o hospitalis, a sancta domus passaram a ser concebidos como sujeito de direito, de natureza ideal $^{(10)}$.

Observa Ferrara que as primeiras fundaçōes, de benemerência e culto, acham-se incorporadas e confundidas com a personalidade das igrejas, mas que aos poucos vão adquirindo autonomia até se afirmarem como entes em si, embora sob a proteção e vigilância eclesiásticas ${ }^{(11)}$. Com base ainda na autoridade de Ferrara, pode-se tomar como ponto de partida desse desenvolvimento o decreto de Constantino que reconheceu as comunidades eclesiásticas cristãs; a partir desse reconhecimento, essas comunidades adquirem capacidade privada, podem ter patrimônio e, efetivamente, passam a receber doaçōes e legados. Desse modo, "os privilégios concedidos às igrejas foram estendidos às piae causae, destinadas a fins religiosos, educacionais e caritativos; essas piae causae já aparecem, no Império Romano posterior, como instituiçōes públicas eclesiásticas dotadas de personalidade jurídica segundo o direito comum. $\mathrm{O}$ florescimento da caridade, fundamentada no Cristianismo, alentada pela Igreja e favorecida pelos imperadores, é um dos momentos mais notáveis da cultura bizantina (Philipsborn, Les établissements charitables et les théories de la personalité juridique dans le droit romain, Revue Internationale des Droits de l'Antiquité, 6:141 e s., 1951)"(12).

A personalidade jurídica das piae causae, independente das pessoas naturais de seus administradores, legantes ou doadores e destinatários, marca momento importante na evolução do direito ocidental que, não obstante, parece retroceder por influência do direito germânico; ensina Cunha Gonçalves que o direito germânico "nunca logrou realizar a abstração de supor, nas sociedades, um ente distinto da coletividade dos indivíduos. As suas marken, genossenschaften, ghilde, etc., não são pessoas; elas são, apenas, uma gesammte Hand, isto é, a unidade imanente na pluralidade dos sócios (...) que não eram excluídos da propriedade do patrimônio das sociedades - gesammte Hand- mas detinham uma espécie de propriedade imperfeita; essa concepção materialista repercutiu na teoria das fundaçōes, onde ao direito germânico parece impossível a

(10) Cfr. Gonçalves, Luiz da Cunha, Tratado de direito civil, vol. 1, 2ª ed., São Paulo, Max Limonad, pág. 903.

(11) Ferrara, f., o.c., pág. 37.

(12) Coelho, Luiz Fernando, o.c., pág. 12. 
existência de um patrimônio dotado de personalidade ideal; assim, constituem propriedade dos santos, aos quais são dedicados os hospitais, conventos, escolas e outras piae causae"(13).

As três correntes de pensamento: romana, germânica e canônica influíram nos juristas da Idade Média e a doutrina dos glosadores, os quais se ativeram de preferência à orientação germânica, admitindo, todavia, o conceito romano da universitas, ao contrário dos canonistas, tendo à frente SINIBALDO DEI FIESCHI, o futuro Papa Inocêncio IV, que se mantiveram fiéis ao sistema canônico, que foi o que veio a prevalecer no direito comum ${ }^{(14)}$.

\section{5 - Expansão no Ocidente}

A partir do século XVIII registra-se notável expansão das fundaçōes, especialmente nos EUA, onde os problemas sociais decorrentes da Guerra da Secessão (1861-1865) exigiram considerável esforço do governo e dos particulares. Entre os pioneiros das fundações americanas, citam-se Benjamin Franklin, doador de grandes somas de dinheiro às cidades de Boston e Filadélfia, em 1790, para empréstimo a jovens artífices, e George Peabody, instituidor, em 1867, do Peabody Educational Fund, destinado à educação nos Estados do Sul e do Sudoeste norte-americano; o Smithsonian Institution, fundado por James Smithson, data de 1846.

Mas, a proliferaçāo das fundações americanas é decorrência direta do extraordinário progresso econômico da nação americana, e, mais que isso, ao fenômeno da concentração de riquezas incalculáveis em mãos de particulares, que se defrontaram com a responsabilidade de fazer a comunidade a que pertenciam participar dos frutos dessa riqueza; assim é que uma extensa e valiosa rede de universidades, bibliotecas, museos, teatros, orquestras sinfônicas, hospitais, orfanatos, etc., expandiu-se por toda a América do Norte e mesmo fora do país; paralelamente ao espírito público de alguns verdadeiros mecenas da época moderna, encontraram as grandes empresas industriais, na instituição fundacional, um meio de diminuição de lucros tributáveis, carreando com isso somas incalculáveis de dinheiro e bens que, ao invés de serem pagos diretamente ao Estado sob forma de tributos, configuravam espécie de pagamento indireto, já que ocorria em favor da comunidade, no amparo à pesquisa e ao ensino, no financiamento das atividades culturais e manutenção de necessitados, tudo isso incentivado por uma legislação inteligente e realmente voltada para o bem comum.

(13) Gonçalves, Luiz da Cunha, o.c., pág. 901.

(14) Serpa Lopes, Curso de direito civil, vol. I, pág. 350. 
A atualidade nos apresenta cerca de treze mil fundaçōes, sendo que as cinco maiores são a Ford Foundation, a Rockefeller Foundation, a Duke Endowment, a John A. Hartford Foundation e a Carnegie Corporation, da cidade de Nova Iorque.

Na Europa, três instituições se destacam particularmente: a Fundação Nobel, da Suécia, a Guggenheim Memorial Foundation, da Grā-Bretanha, e a Fundação Calouste Gulbenkian, de Portugal. Também a Humbolt Stiftung, da Alemanha Ocidental, é das mais importantes, pelo alcance mundial de sua açāo.

\section{6 - Desenvolvimento no Brasil}

No nosso direito anterior, as fundações eram reconhecidas e "gozavam de personalidade jurídica, incluídas entre estas os corpos de mão morta, segundo se conclui dos termos do Título XVIII, do Livro II das Ordenações do Reino, disposiçōes que tiveram fonte nas Concordatas de D. Diniz, D. Pedro I e D. João I. (V. CÂNDIDO MENDES, Ordenações Philipinas, anotações ao Livro II, tit. XVIII e COELHO DA ROCHA, Direito Civil Português, 1º, pág. 49).

E como pessoas jurídicas foram incluídos na Nova Consolidação, art. 152 , podendo ser instituídas por ato entre vivos, ou por testamento (art. 155), sendo a autoridade competente para a aprovação dos estatutos os juízes de provedoria. (RIBAS, Proc. Civil, arts. 39, 40), sujeitos ainda a interferência do Ministério Público"(15).

No Brasil, os estabelecimentos fundacionais mais antigos são a Casa dos Expostos e a Santa Casa de Misericórdia, do Rio de Janeiro, que datam dos primeiros tempos da colonização. Mas constituem marcos importantes no desenvolvimento histórico de nossas fundaçōes a Fundação Diocesana Pão dos Pobres, de Porto Alegre, a Fundação Abrigo Cristo Redentor, a Fundaçāo Darcy Vargas, a Fundação Getúlio Vargas e a Fundação Brasil Central. Em relação a esta, ensina Franco Sobrinho que, instituída pela União Federal, nos termos do Decreto-lei no 5.878, de 4-10-1943, com personalidade jurídica de direito privado e tendo sede e foro no Rio de Janeiro, aparece como "a primeira grande organizaçāo fundacional governamental, num estilo assemelhado ao sistema político brasileiro e adaptada às regras do processo jurídico privado tradicional no que concerne a esses tipos de entes',(16).

(15) Gusmão, Sady Cardoso, Fundação in Repertório Enciclopédico do Direito Brasileiro, vol. XXIII, Editor Borosi, Rio de Janeiro, s.d., pág. 221.

(16) Franco Sobrinho, Manuel de Oliveira, Fundações e empresas públicas, São Paulo, Ed. R.T., 1968, pág. 58. 


\section{II - CONCEITO}

\section{1 - Definições}

Para Pontes de Miranda, é pessoa quem pode ser sujeito de direito, quem tem ingresso, como termo, nas relações jurídicas; o nascimento é um suporte fático sobre o qual incidiu a regra jurídica, tornando-o, destarte, fato jurídico; do mesmo modo, $o$ ato de atribuir personalidade jurídica é suporte fático, sendo que a diferença entre fundação e sociedade vem desde o suporte fático; ao contrário das pessoas do tipo societário, no suporte fático de que sai a fundação não há pluralidade de pessoas; não há ficção e nem direitos sem sujeito, muito menos organização personificada; o que existe é uma pessoa jurídica que nasce do negócio jurídico fundacional, a declaração de vontade do fundador; essencial ao negócio é a vontade de criar sujeito de direito, com especificação dos fins e os meios com que pode contar, inicialmente; assim, como elementos necessários da fundação, têm-se o fim e o patrimônio. Segundo esse autor, a doutrina tradicional, que mais convém a texto como o do art. 24 do Código Civil brasileiro e art. 80 do Código Civil suíço foi no sentido de ser exigido como substrato o patrimônio. Mas considera que o patrimônio é um dos pressupostos do negócio jurídico fundacional, pressuposto que pode ser satisfeito com a simples promessa de dotação de bens ${ }^{(17)}$.

Clóvis Beviláqua, em comentário ao art. 24 do Código Civil, define: "Fundação é uma universidade de bens personalizada, em atenção ao fim que lhe dá unidade"; na Teoria Geral, define a fundação como "um patrimônio transfigurado pela idéia, que o põe ao serviço de um fim determinado"(18).

E Orlando Gomes: “A fundação é uma pessoa jurídica de tipo especial... Constitui um acervo destinado ao cumprimento de determinado fim... Numa palavra, um patrimônio destinado a um fim... A atribuição de personalidade ao conjunto de bens que alguém destina à realização de certo fim é um recurso técnico necessário a que a obra possa sobreviver a seu criador"(19).

Entre os jusadministrativistas, o caráter essencial do patrimônio como suporte fático da personalidade jurídica da fundação é também geralmente acatado. Assim, conceitua Oliveira Franco Sobrinho, apoiado em Clóvis Beviláqua: Sabemos, por ser pacífico, que a fundação se define como um conjunto de bens personificados conforme a vontade de seu instituidor, abrangendo no seu con-

(17) Pontes de Miranda, Tratado de direito civil privado, parte geral, 1954, t.1, $\S 75$, 102 e 104.

(18) Beviláqua, Clóvis, Teoria Geral do direito civil, $7^{\text {a }}$ ed., 1955, pág. 118.

(19) Gomes, Orlando, Introdução ao direito civil, R.J., Forense, 1975, pág. 186. 
ceito os diferentes ramos do direito, e personalizada em atenção do fim que the dá unidade ${ }^{(20)}$.

No mesmo sentido, Themístocles Brandāo Cavalcanti, citando Von Stein: "As fundaçóes representam pessoas jurídicas de caráter muito peculiar, e consistem em complexos de bens (universitates bonorum) dedicados à construçāo de certos fins e para esse efeiter dotados de personalidade"(21).

Pode-se, pois, "definir fundação como um 'patrimônio personalizado dirigido a um fim'. Ou, como queria Ferrara: 'é una organizzazione per uno scopo'. De fato, estabelece o Código Civil no seu art. 24:

'Para criar uma fundação, far-lhe-á o seu instituidor, por escritura pública ou testamento, doação especial de bens livres, especificando o fim a que se destina e declarando, se quiser, a maneira de administrá-la'.

Assim, perante o direito brasileiro, a idéia de fundaçāo vazia, sem patrimônio, é inadmissível, princípio que convém desde logo fixar, pois para o mesmo nem sempre atentam as pessoas que imaginam criar entidades dessa natureza"(22).

\section{2 - Elementos básicos}

A fundação constitui uma espécie de pessoa jurídica, cuja composiçāo interna resulta da destinação por alguém de um patrimônio vinculado a certo fim específico e lícito e, nesse sentido, estatui o art. 24 do Código Civil.

Donde a existência dos seguintes pressupostos:

a) um ato jurídico formal constante de escritura pública ou testamento; b) um complexo de bens livres a ela destinados; c) a menção no ato do fim especial de instituiçāo; d) a indicaçāo de pessoa ou pessoas as quais compete a elaboração dos estatutos, quando não constarem do ato.

Clóvis inclui entre os requisitos esses estatutos e a administração, o que é também admitido por Serpa Lopes ${ }^{(23)}$.

(20) França Sobrinho, Manuel Oliveira, As fundações e o direito administrativo, in Revista de Direito Administrativo da FGV, 100, pág. 9.

(21) Cavalcanti, T.B., Tratado de direito administrativo, 5ª ed., v. III, pág. 133.

(22) Monteiro, Clovis Zebaran; Senna, Homero, Fundaçōes, No Direito, Na Administração, Instituto de Documentação da FGV, Rio de Janeiro, $1^{\text {a }}$ ed., 1970, pág. 101.

(23) Serpa Lopes, o.c., pág. 351. 
Pontes de Miranda, estudando o assuntos nos $\S 162$ e seguintes do seu Tratado de Direito Privado (tomo I) não inclui esses requisitos últimos, entre os pressupostos.

$\mathrm{Na}$ verdade o Código Civil não as menciona de modo preciso no art. $24 \mathrm{e}$, na conclusão desse dispositivo, apenas estabelece: especificando o fim a que se destina, e declarando, se quiser, a maneira de administrar.

Não há referência assim a estatutos nem forçada designação do modo de administrar.

Por isso, o mesmo Pontes de Miranda distingue o ato da instituição e o ato da fundação, sustentando que algumas vezes o instituidor não funda (não é fundador). Isso acontece sempre que os estatutos não foram elaborados pelo instituidor, ou se a verba testamentária se há de interpretar como encargo ao herdeiro ou legatário, ou dever do testamenteiro ${ }^{(24)}$.

Quer nos parecer, no entanto, que a existência das fundações comporta três momentos: o da instituição (fundaçāo imperfeita ou instituída), o da organização (fundação organizada); o do registro, para que adquira personalidade jurídica, nos termos dos arts. 18 e 19 do Código Civil, tornando-se fundação perfeita, isto depois da aprovação dos estatutos, como "ato do poder público, constitutivo integrativo dos mesmos estatutos, sendo a aprovação elemento essencial à fundação, não suprível pelo registro"(25), como observa Pontes de Miranda.

Certos patrimônios déstinados a um fim permanente ou específico, "embora não sejam fundaçōes, têm semelhanças com estas, como as coletas e subscriçōes públicas, em que alguns vêem mandato e outros sociedade, e que não dão pretensões legítimas aos destinatários contra coletores, subscritores ou depositários de tais valores, salvo se a coleta se fez para determinada pessoa ou pessoas, segundo critério pré-estabelecido, explícita ou implicitamente. A estas coletas chama Demburg empresas de utilidade comum, aplicando-se a elas o que for conforme à sua natureza.

Este mesmo autor, sustentando que, em sentido estrito, a fundação é um patrimônio dedicado a fins úteis, com personalidade independente, reconhece que, em sentido mais amplo, são fundaçōes também os patrimônios que são destinados a determinados fins, doados a um sujeito de direito já existente, como o fisco, a municipalidade, uma igreja, uma universidade. E o fundador e seus herdeiros têm direito a exigir a aplicação do dito patrimônio (Pandette, Parte Geral e Parte 1ª, página 183)"(26).

(24) Pontes de Miranda, o.c., $§ 104,2$.

(25) Ibidem, pág. 465.

(26) Gusmão, Sady C., o.c., pág. 220. 
Todavia, estes e outros casos semelhantes se resolvem de acordo com os princípios pertinentes às doaçōes com encargo.

O caráter do negócio jurídico criativo de fundação, no dizer de Pontes de Miranda, é o de um ato unilateral do instituidor, formal e gratuito.

A unilateralidade é própria do instituto, o seu caráter formal provém de exigência de escritura pública, ou testamento, ressalvadas as fundações a que se fez referência antes, de caráter pio e religioso, de existência secular.

É ato gratuito específico, não equivalendo a doação, é liberalidade, sim, mas com fins específicos, donde o não depender de aceitação.

Alguns autores alemães, citados por Pontes de Miranda, sustentam a validade da fundação vazia, ou sem patrimônio, o que não se pode admitir no direito brasileiro, ante o que estatuem os arts. 24 e 25 do Código Civil, a despeito de tais bens poderem ser futuros.

Pontes de Miranda considera irrevogável o ato e assim deverá ser, como toda declaração unilateral da vontade, desde que haja produzido efeitos no mundo exterior, sob a hipótese de falta dos requisitos legais ${ }^{(27)}$, ou quando a instituição é feita em testamento, dada a natureza do testamento, como ato essencialmente revogável.

Não obstante, se não tratar de doação (não incidindo as normas destas, como a de revogação de doação por ingratidāo) é inadmissível a instituição com doação em vida, de todos os bens do instituidor, sem reserva do necessário para sua subsistência, nem a lesão de legítima dos herdeiros necessários (quando se trata de testamento), como observa o mesmo Pontes de Miranda ${ }^{(28)}$.

A elaboração dos estatutos, seu registro, compete às pessoas nomeadas no ato, quando não os houver redigido o instituidor, tudo dependendo da aprovação dos estatutos, pelo Ministério Público, o qual, em relação às fundaçōes é, uma vez, agente, assistente e consulente.

A aprovação dos estatutos é indispensável e necessária à personificação, sendo parte integrante do negócio em causa, para projeçāo da fundação na ordem e vida externa, respondendo funcionalmente o oficial que efetua o registro, sem tal aprovação, notando-se mais que a inscriçāo no caso tem caráter constitutivo e não simplesmente declaratório, por essencial para o funcionamento da fundação e para a atribuiçāo a esta qualidade de pessoa jurídica.

(27) Pontes de Miranda, o.c., \& 104, 7.

(28) Ibidem, § 105, 2. 
Esse caráter constitutivo, entretanto, é relativo, porque não dá existência à instituição, esta já existe, mas se refere à vida externa da fundação e à condição da pessoa jurídica.

Cabe a inscrição ao próprio instituidor, ou à pessoa a quem for confiada tal incumbência, e se presume autorizada a que for encarregada de elaborar os estatutos, ou a qualquer das indicadas como administradoras.

Poderá promovê-la, também, o Ministério Público, por si, ou a requerimento de qualquer interessado.

Os estatutos podem ser alterados, com intervenção do Ministério Público, nos termos do art. 28 do Código Civil, ou seja: a) mediante deliberação da maioria absoluta dos componentes da sua diretoria, ou administração; b) desde que a deliberação não contrarie os fins da fundação; c) com aprovação da autoridade competente, ou seja do Ministério Público ${ }^{(29)}$.

\section{3 - Personalidade jurídica}

Sabemos que a personalidade natural se inicia com o nascimento com vida, muito embora a lei proteja, desde a concepção, os direitos do nascituro (Código Civil, art. 4\%). Já na "gestação" da pessoa jurídica, para usarmos uma expressão de Caio Mario da Silva Pereira, há duas fases: a do ato constitutivo e a da formalidade administrativa do registro.

E há essas duas fases porque, a respeito, o direito brasileiro se filia ao chamado sistema das disposiçōes normativas. De fato, pode o legislador adotar três critérios para atribuição de personalidade jurídica a tais entidades: o da livre formação, o do reconhecimento e o das disposições normativas. $O$ primeiro não impõe qualquer condição ou requisito para a criação da pessoa jurídica, sendo para tanto suficiente a simples elaboraçāo do seu ato constitutivo. O sistema de reconhecimento, adotado, entre outros, pelo direito português e francês, exige, para a criação das pessoas jurídicas, como o próprio nome indica, um ato prévio de reconhecimento.

O terceiro critério, chamado das disposiçōes normativas, fica a meio caminho dos outros dois, podendo, por isso, ser considerado um sistema eclético. À vontade dos membros componentes da entidade, desde que manifestada de forma hábil, é atribuído poder criador, independentemente de qualquer ato administrativo de concessão. Mas a outorga da personalidade jurídica fica subordinada à observância de condiçōes legais predeterminadas. Uma vez satisfeitas essas condiçōes, a entidade passa a ter vida própria e pode operar livremente.

(29) Cfr. Gusmão, Sady C., o.c., pág. 222. 
O direito brasileiro filia-se, pois, ao sistema das disposições normativas, muito embora sem rigidez; na verdade, nenhum direito contemporâneo guarda absoluta fidelidade a um só sistema. Caio Mario da Silva Pereira enquadra o nosso direito no das disposições normativas porque, salvo casos especiais de exigência de autorização prévia (exploração de jazidas do subsolo, quedas d'água, atividades. bancárias, de seguro, etc.), o princípio dominante, entre nós, é o de que a vontade dos indivíduos, desde que manifestada de forma hábil, é dotada do poder de criar a pessoa jurídica ${ }^{(30)}$. Mas personalidade in fieri, permanece em estado potencial até que, preenchidas as exigências legais, se investe do status de pessoa jurídica.

No concernente ao ato constitutivo, há distinçōes a fazer, conforme se trate de associações ou fundações.

Para as primeiras, considera-se ato constitutivo um ato escrito qualquer, por meio do qual se estabeleça entre várias pessoas naturais (ou mesmo entre várias pessoas jurídicas previamente constituídas), o compromisso para a consecução do fim comum Ato escrito é, pois, o primeiro requisito para a constituição de uma sociedade ou associação. Esse ato escrito, porém, pode tomar várias formas: pode ser um contrato, um contrato de sociedade, como acontece nas sociedades comerciais e nas sociedades civis; pode ser um estatuto, como acontece principalmente nas associaçōes que se propōem a fins não lucrativos nos clubes, nos centros de estudo, nas associações pias -; e pode ser simples compromisso, quer dizer, um ato que não reveste nem a forma de estatuto nem a de contrato, mas que representa, já, entre as pessoas que se reuniram, o compromisso da consecução do fim visado. Por compromisso constituem-se as ordens beneficientes, ainda hoje tão comuns entre nós: as ordens terceiras, as ordens pias e as ordens monásticas.

Quanto aos requisitos das fundações, antes de mais nada, é importante saber quem as pode criar. Segundo a lição de Beviláqua, elas "podem ser criadas pelo Estado, uma pessoa natural ou uma pessoa jurídica de ordem privada"(31). Mas, evidentemente, para a criação de uma pessoa jurídica dessa natureza, "fazem-se necessários alguns requisitos que são: a) patrimônio composto de bens livres no momento da constituição; b) o ato constitutivo ou a dotação, que deverá constar da escritura pública ou testamento; c) a declaraçāo, nesse ato, do fim especial a que se destina a fundaçāo; d) estatutos, que atenderāo às bases deixadas pelo instituidor; e e) uma administração.

(30) Silva Pereira, Caio Mário, Instituições de direito civil, 2ª ed., Rio de Janeiro, Forense, 1966, v. I, pág. 200.

(31) Beviláqua, Clovis, Código Civil Comentado, 5ª ed., Francisco Alves, 1936, pág. 232. 
Lembra San Tiago Dantas, que as fundações se constituem de modo mais complexo do que as associações e que, no concernente às primeiras, temos de distịnguir dois tempos: um é a instituição (ato unilateral, formal e gratuito) e o outro é a constituição propriamente dita. Segundo a distinção por ele estabelecida, 'instituição é o ato graças ao qual uma pessoa, ou um grupo de pessoas, toma um patrimônio e o destina a um determinado fim'. Nesse ato, o instituidor deve prever desde logo quem ficará incumbido de organizar a pessoa jurídica, quando se dará então o segundo momento, ou seja, a constituição propriamente dita da fundação",(32).

Na verdade, porém, nem sempre ocorrem esses dois momentos, pois, como lembra Washington de Barros Monteiro, há duas maneiras de formação das fundaçōes: direta (o próprio instituidor cuida de todo o necessário) e fíduciária (o instituidor delega a outrem a organização da obra projetada) ${ }^{(33)}$.

As fundaçōes criadas por atos inter vivos em geral são diretas, muito embora possam também revestir a segunda forma, ocorrendo a criação fiduciária nas fundaçōes instituídas por atos mortis causa.

\section{II - 4 - Associaçōes e Fundações}

Consoante a lição de Clóvis Beviláqua, "as pessoas jurídicas de direito público precederam as pessoas naturais que delas se foram, pouco a pouco, destacando, como de uma nebulosa primitiva", já que "o agente do direito originariamente nem sempre é o homem individualmente considerado, mas, na maioria dos casos, a coletividade a que pertence e que o absorve"(34).

Assim, há pessoas jurídicas de direito público (intemo ou externo) e de direito privado. Segundo o Código Civil Brasileiro, são pessoas jurídicas de direito público interno: I - A União. II - Cada um dos seus Estados e o Distrito Federal. III - Cada um dos Municípios legalmente constituídos (art. 14).

Quanto às pessoas jurídicas de direito privado, são elas: I - As sociedades civis, religiosas, pias, morais, científicas ou literárias, as associaçōes de utilidade pública e as fundaçōes. II - As sociedades mercantis, que se regem pelo estatuído nas leis comerciais (Código Civil, art. 16).

Dentre as pessoas jurídicas de direito privado, interessam-nos particularmente, neste trabalho, as associações e as fundações, convindo fixar desde lo-

(32) Senna, Homero, o.c., pág. 106.

(33) Monteiro, Washington B., Curso de direito civil, 4ª ed., Saraiva, S. Paulo, 1964, vol. I, pág. 126.

(34) Beviláqua, Clóvis, Em defesa do Projeto de Código Civil brasileiro, Rio de Janeiro, Francisco Alves, 1906, pág. 65. 
go os traços diferenciais que as distinguem: "enquanto nas associações o que domina é o elemento pessoal, nas fundações o que prevalece é o elemento patrimonial. Enquanto que na organização de uma associação temos principalmente em vista as pessoas que se reúnem, que se associam visando a determinado fim, nas fundações temos em vista principalmente um patrimônio que se constitui com vistas a um objetivo preestabelecido"(35).

"Como acentua San Tiago Dantas, isto não quer dizer que possamos conceber uma pessoa jurídica que não seja essencialmente uma reunião de pessoas naturais: em toda fundação as pessoas naturais são necessárias como membros delas, como executoras da vontade coletiva"(36). Contudo, nas fundações, ao contrário do que ocorre nas associações, essas pessoas têm importância secundária; o que tem, principalmente, sentido é o patrimônio afetado à consecução de determinado fim. Já nas associaçōes ou sociedades, as pessoas é que importam em primeira linha e o patrimônio constitui-se como um aspecto secundário da entidade.

No direito brasileiro, a distinção clássica entre fundações e associações pertence a Lacerda de Almeida, que, a propósito, escreve:

"O que caracteriza in genere os estabelecimentos, e in specie as fundações, é servirem a um fim de pública utilidade - religioso, moral, científico, político, ou mesmo industrial - e nisto se distinguem das associações ou corporações, as quais, posto possam ter fins idênticos ou análogos, não servem a tais fins, antes no alcançá-los buscam o seu próprio proveito, trabalham no interesse da coletividade ou do ser ideal que as personifica. Por isso mesmo que são pessoas e não coisa e, como pessoas, têm em si próprias a razão de sua atividade, as associações ou corporaçōes - admita-se a sinonímia destes vocábulos - as associações ou corporações são do mesmo modo e pelo mesmo título que as pessoas físicas, fim para si, trabalham, agem, movem-se, dirigem-se para servir a si próprias, tudo o que fazem, fazem-no no interesse próprio; os direitos que adquirem, adquirem-nos, para si e para si os exercem. As fundações, os institutos, os estabelecimentos, são, ao contrário, estruturas destinadas a servir a certos fins de religião ou de beneficência ou de ciência ou arte, etc., não são pessoas, mas coisas personificadas, não são fins para si, adquirem direitos e exercem-nos em proveito de certa classe de pessoas indeterminadas, ou de quaisquer pessoas indistintamente. São patrimônios administrados; a personalidade deles pode considerar-se uma abstração",(37).

(35) Guimarães, H., As pessoas jurf́dicas como situações patrimoniais, in Revista Forense, 91(471): 299-310, 1942.

(36) Senna, Homero, o.c., pág. 96.

(37) Lacerda de Almeida, Das pessoas jurídicas; ensaio de uma teoria, Rio de Janeiro, Revista dos Tribunais, 1905, pág. 66-67. 
A distinção estabelecida, de modo magistral, por Lacerda de Almeida, nos princípios do século, encontra confirmação no ensinamento dos mais modernos tratadistas, como por exemplo, Mario Allara, da Universidade de Turim, que, 'acentuando a função ativa da associação - que age para atingir um objetivo comum aos associados - e a função passiva da fundação - que age para atingir um objetivo fixado por outro (o instituidor), observa:

"Noi diciamo invece che la differenza tra associazione e fondazione consiste nel diverso atteggiamento delle'elemento personale: nella associazione, la collettività organizzatta (tale organizzazione può essere simultanea e sucessiva) agisce per il raggiungimento di uno scopo comune agli associati, e portanto questi ultimi esplicano una funzione attiva, una libera attività; nella fondazione invece la collettività organizzatta agisce per il raggiungimento di uno scopo stabilito da altri (il fondatore), e portanto detta colletività esplica una funzione passiva; la vita della fundazione è retta dalla volontà, esterna, del fondatore" ${ }^{(38)}$.

Tornando bem clara a distinção entre associações e fundações, San Tiago Dantas dá os seguintes exemplos:

Amanhã resolvemos fundar uma universidade e desejamos que e essa instituição sobreviva no tempo e tenha determinada orientação. Dois caminhos se nos oferecem: Escolhermos outras pessoas que tenham as mesmas idéias e preocupações e fundarmos com elas uma entidade, à qual daremos um estatuto, onde estará prevista a forma de gestão do respectivo patrimônio. Nesse caso, teremos obedecido à técnica da associação.

Mas - lembrava, em suas aulas, o saudoso mestre - podemos seguir caminho diverso. Mediante dotação especial, formaremos preliminarmente um patrimônio e em seguida fundaremos a universidade, dispondo, nos respectivos estatutos, sobre os critérios a serem observados na escolha dos professores, na seleção dos alunos, na administração dos cursos, etc. Neste segundo exemplo teremos obedecido à técnica da fundação. Aqui o que avulta é o patrimônio elemento formador da entidade -, porque o tomamos e o destinamos à consecução daquele fim, enquanto que, no primeiro exemplo, o que avultava era a reuniāo de várias pessoas que, depois de congregadas, obteriam um patrimônio e disporiam sobre ele deste ou daquele modo ${ }^{(39)}$.

Vicente Ráo já observou que "o art. 16 de nosso Código Civil consagra um conceito unitário de personalidade jurídica, nele incluindo as duas modali-

(38) Giappichelli, Le nozioni fondamentali del diritto civile, 5a ed., Torino, 1958, v. I, pág. 233; apud Senna, Homero, o.c., pág. 99.

(39) Senna, Homero, o.c., pág. 99. 
dades típicas de direito privado que são as sociedades (de fins econômicos ou não econômicos) e as fundaçōes", com o que obedeceu à tendência doutrinária a que De Ruggierò alude nestes termos: "Tende la dottrina più moderna, decisivamente, all'unità del concetto di persona giuridica, ad una costruzione dogmatica unica, che abbracci ambedue forme e le riduca ad unica concezione" (Inst., v. $1, \S 42)^{(40)}$.

\section{A propósito, escreve Caio Mario da Silva Pereira:}

"Análoga às sociedades e associações nos resultados da personalização, delas difere a fundação, essencialmente, na sua constituição, que não se origina, como aquelas, de uma aglomeração orgânica de pessoas naturais. $O$ que se encontra, aqui, é a atribuição de personalidade jurídica a um patrimônio, que a vontade humana destina a uma finalidade social. $\mathrm{B}$ um pecúlio, ou um acervo de bens, que recebe da ordem legal a faculdade de agir no mundo jurídico e realizar as finalidades a que visou o instituidor",(41).

Constituirá, porém, uma fundação qualquer dotação patrimonial vinculada a fins determinados, como, por exemplo, a entrega de bens ou recursos financeiros a um estabelecimento de ensino, com a finalidade específica de conceder "bolsas de estudos" a universitários?

A esta indagação, o mesmo autor responde negativamente, acentuando, com toda a procedência:

"Para que uma destinação de bens passe a constituir fundação é necessária a personificação, isto é, aquisição de personalidade jurídica própria, de que lhe advém a capacidade jurídica para atuar. Não se confunde com uma doação (Oertmann), porque esta envolve a transferência de bens de uma pessoa a outra, enquanto que na fundação a dotação patrimonial é o elemento genético de uma pessoa jurídica. Não há fundação, por exemplo, nos patrimônios por subscrições para um fim determinado, como, por exemplo, socorrer flagelados. Precisamente em razão daquele abstracionismo que permite personificar um patrimônio em função do fim a que se destina, o direito romano somente viria a sentir e criar as universitates bonorum muito tarde, já numa fase em que a inspiração cristã da pia causa conduziu o pensamento do jurista à outorga de capacidade ao acervo patrimonial animado pela vontade vivificadora. A personificação das fundações, realizada em visível paralelo com a das sociedades e associações, é, entretanto, muito mais técnica, porque, se nas associaçōes de pessoas a reunião de suas vontades vivas é o substractum da personalidade, como acentua De

(40) Ráo, Vicente, O direito e a vida dos direitos, Sẳo Paulo, Max Lemonad, s.d., v. II, pág. 270.

(41) Silva Pereira, Caio Mario, o.c., pág. 210. 
Page, na fundação ela está na idéia ou na afetação patrimonial, tomada em consideração para se destacar da vontade criadora e cumprir com autonomia a sua destinação"(42).

As pessoas jurídicas do tipo fundacional são constituídas por um patrimônio, conjunto de bens, a que a ordem jurídica atribui a personalidade jurídica; nisto radica a differentia specifica de tais entidades, na natureza do suporte factual ao qual a ordem jurídica reconhece atributos de sujeito de direito, com aptidão para a titularidade de direitos e obrigaçōes; na associação, o que existe de fato é um grupo de pessoas, tratado normativamente como se fora uma só e sem prejuízo da personalidade juridicamente reconhecida de cada um dos seres integrantes do grupo; na fundação, esse suporte para o sentido jurídico normativamente atribuído é um patrimônio.

Os demais caracteres das fundações, tais como o modo de sua constituição, administração e representação, são fatores acidentais, dependentes das peculiaridades do sistema jurídico de cada época e lugar.

\section{5 - Concepçōes na legislação e doutrina estrangeiras}

No direito francês, as fundaçōes somente se investem de personalidade jurídica à vista de um decreto expedido após pronunciamento do Conselho de Estado.

A idéia de que pode haver fundação sem afetação inicial de patrimônio a um fim, aparece nos autores alemães e tem sido atribuída ao silêncio do Código Civil Alemão acerca da necessidade da dotação patrimonial no ato de fundação.

Efetivamente, o Código Civil Alemão não é tão claro como o Código Civil Suíço, que no artigo 80 diz que "a fundação tem por objeto a afetação de bens a favor de um fim especial", ou nosso Código Civil, segundo artigo 24, "para criar uma fundação, far-lhe-á o seu instituidor, por escritura pública ou por testamento, dotação especial de bens livres, especificando o fim a que a destina...". Mas o $§ 82$ do Código Germânico, quando dispōe que "uma vez a fundação aprovada é o fundador obrigado a transferir para ela o patrimônio que lhe assegurou no ato de fundação", contém implícita a idéia de que não há fundação sem afetação de patrimônio.

Não o tem entendido assim grande parte da doutrina germânica, porventura influenciada por Savigny que, no Tratado de Direito Romano, ao dar nova vida à distinção entre associaçôes e | undações, dizia repousarem estas "sobre um fim geral que lhes é assinado"(43).

(42) Silva Pereira, Caio Mario, o.c., pág. 210.

(43) Savigny, Traité de Droit Romain, trad. for de Guenoux, 1855, vol. II, § 86, no 2; apud Caetano, Marcello, Das Fundações, Ed. Átila, Lisboa, s.d., pág. 8. 
“Lehmann, no estudo que apresentou sobre As fundaçóes no Direito Alemão à Semana Internacional de Direito, realizada em Paris em 1937 (cf. Travaux de la Semaine Internationale de Droit), informa: 'Enquanto o Código Civil Suíço, no seu artigo 80 , inclui a dotação patrimonial como condiçāo expressa do ato de fundação, o Código Civil Alemão passa o assunto em silêncio. É por isso que a opiniāo dominante se inclina para que a fundação possa nascer sem afetação de um patrimônio, respondendo assim às hipóteses em que se verifique serem os bens afetados desprovidos de valor, sem embargo do que a fundação haja conseguido doutro modo adquirir um patrimônio. Mas como a fundação não pode atingir o seu fim senão mediante o emprego de meios patrimoniais, dever-se-á pelo menos exigir que o fundador indique a via pela qual ela poderá obter tais meios' (pág. 27)"(44).

Ferrara admite que a fundação possa ser criada sem patrimônio quando seja seguro que, após a criação, o patrimônio aflua, ainda que por subscrição pública. E cita uma resolução do Conselho de Estado italiano de 1876, sègundo a qual "quando um instituto, pela qualidade das pessoas que o compõem e pelo fim que se propōe, oferece suficientes garantias morais, pode ser criado como pessoa moral ainda que sem patrimônio". Salvo o devido respeito, porém, nesta resolução atende-se a pessoas que compõem o instituto, quer dizer, a um elemento pessoal por definição ausente do momento originário da fundação. Tratase de uma comissão promotora ou de uma associação, não de uma fundação, e nesse caso parece incorreta a solução dada. Que a comissāo promotora de uma subscrição tenha como objeto criar, com o patrimônio coletado, uma fundação, é regular. Que seja desde logo, enquanto é apenas um grupo de pessoas, considerado fundação, é errôneo ${ }^{(45)}$.

O Código de Direito Canônico, proíbe a concessão da personalidade às fundações que não contarem com um dote que baste, ou prudentemente se preveja que possa vir a bastar, à consecução do fim. Esta previsão tem de ser feita a partir de um patrimônio inicial, embora se admita que a suficiência dependa da acumulação de rendimentos, do concurso de esmolas ou donativos, etc. Isto é: o que pode não ser certo, no ato de instituição ou de reconhecimento, não é o patrimônio e sim a sua suficiência.

No Direito português o problema não tem sido discutido. Todos os autores reconhecem que para haver fundação há de existir afetação de patrimônio.

Sem dúvida que podem surgir as hipóteses que estāo por detrás das preocupações dos autores alemães: hipóteses resultantes da depreciação monetária que haja reduzido a nada ou quase nada, no momento da abertura da herança,

(44) Castro, Marcello, o.c., pág. 10.

(45) Ferrara, F., o.c., pág. 53. 
valores que na data do testamento eram suficientes para a realizaçāo do fim visado, ou até tenha aniquilado esses valores entre a data da aprovação pelo Estado e o início efetivo da realização da obra.

Em qualquer dessas hipóteses, porém, o patrimônio existiu no momento do ato de instituição e o problema põe-se apenas quanto à impossibilidade de atingir o fim visado pelo fundador em virtude de circunstâncias supervenientes $^{(46)}$.

\section{III - OUTRAS CARACTERÍSTICAS}

\section{1 - Tempo de duração}

Questão que desde logo se coloca, quando se examina o problema das fundações, é a que se prende à duração de tais entidades. Deverão elas ser perpétuas?

Diante de certos códigos que expressamente admitem as fundações temporárias, como o Código Civil brasileiro, art. 30, e o Código Civil italiano, arts. 16 e 28 , há quem ponha em dúvida se, neste caso, estaremos diante de uma verdadeira fundação.

Decorre esta posição do entendimento, geralmente aceito, de que as fundaçōes obedecem, na sua gênese, "à ânsia que o fundador tem de ganhar na terra um pouco da eternidade a que todo homem aspira" Por isso, a maioria delas é estabelecida por tempo indeterminado, "na esperança de que a sucessão dos séculos respeite a memória do instituidor".

Marcello Caetano lembra, porém, o quanto esta esperança é ilusória, pois inúmeras fundaçōes instituídas através dos séculos já estão esquecidas. De fato, como assinala o ilustre tratadista português:

"O minguar dos patrimônios, a transformação dos valores, a alteração das necessidades ou dos meios de lhes dar satisfação, a mudança de concepçōes políticas e sociais, a luta contra os bens de mâo-morta e a negligência dos homens tornam temporário o que audaciosamente se quis eterno. A perpetuidade é, pois, relativa",(47).

Mas, embora não sejam necessariamente perpétuas, as fundações devem ser permanentes, usada esta palavra para exprimir uma idéia de duração, "por

(46) Cfr. Caetano, M., o.c., pág. 11.

(47) Caetano, M., o.c., pág. 15. 
oposição ao que é efêmero, eventual, circunstancial". Pode essa duração, porém, ser por tempo limitado.

Realmente, como assinala o autor citado:

"Não se vê que inconveniente possa existir em admitir fundações para fins temporários (por exemplo, fundação de auxílio aos combatentes da Guerra de 1914, que se extinguiria com a morte do último dos possíveis beneficiários) ou por tempo determinado (por exemplo, uma fundação para formação de técnicos de energia nuclear, com a duração de trinta anos)".

Aprofundando a discussão da idéia, Marcello Caetano chega a sustentar que "estas fundações temporárias podem então ter por patrimônio, não um capital, mas uma renda ou um rendimento que lhes seja consignado", concebendo-se até que, "sendo a duração determinada, receba um capital, mas com o direito de ir consumindo segundo um plano tal que a sua extinção coincida com o termo da fundação"(48).

No Brasil, diante do texto legal, essas especulações doutrinárias perdem o interesse, já que o Código Civil, no seu art. 30, expressamente dispōe:

"Verificado ser nociva ou impossível a mantença de uma fundaçāo, ou vencido o prazo de sua existência, o patrimônio, salvo disposição em contrário no ato constitutivo, ou nos estatutos, será incorporado em outras fundações, que se proponham a fins iguais ou semelhantes".

Ultimamente, porém, temos tido, entre nós, casos de fundaçōes que de modo algum observam esse princípio do Código Civil. Fundações nitidamente impossíveis, por falta de condições materiais de subsistência, continuam a ser mantidas, quase sempre à custa do Tesouro Nacional. E ninguém se lembra de sugerir sejam os respectivos patrimônios incorporados em outras entidades da mesma natureza que se proponham a fins iguais ou semelhantes. É verdade que isto ocorre principalmente com as chamadas fundações públicas.

\section{2 - "Fundações Públicas"}

Um dos assuntos mais polêmicos da doutrina brasileira na atualidade é o concernente à natureza jurídica das fundaçōes que, sem terem sido instituídas por particulares, o foram pelo poder público, mediante a destinação de bens e sua personificação sob a forma fundacional.

Essas entidades são chamadas fundações públicas, em razão da origem pública do seu patrimônio, mas também recebem a designação errônea de fun-

(48) Caetano, M., o.c., pág. 16. 
daçōes de direito público; entidades instituídas pela administração estatal, na esteira das fundaçōes privadas desenvolvidas no campo do direito civil, têm atraído a atenção de juristas, advogados, administradores e políticos, em parte porque têm constituído instrumento dos mais utilizados na ação governamental da União, dos Estados e dos Municípios, e em parte porque a doutrina jurídica e a jurisprudência têm acatado interpretações divergentes e mesmo conflitantes a respeito das regras que as definem no direito positivo e regulam sua atuação.

$\mathrm{O}$ assunto tem consideráveis reflexos para o direito administrativo; problemas como o do regime jurídico do pessoal dessas fundaçōes, o da extensāo a elas dos privilégios processuais do Estado, o da acumulaçāo de cargos públicos, têm sua solução freqüentemente dimanada da equiparação dessas fundações públicas, ora às autarquias, com personalidade jurídica de direito público, ora às fundações privadas, instituídas nos termos dos arts. 24 e s. do Código Civil. Acresce que o panorama atual do direito brasileiro evidencia a insegurança do legislador em definir o regime jurídico de tais entidades; pode-se verificar uma tendência privatista do legislador federal - o Decreto-lei no 200, de 25-2-1967, equiparou as fundações públicas às empresas públicas, estas definidas como pessoas jurídicas de direito privado, e o Decreto-lei no 900 , de 29-9-1969, excluiu-as da administração indireta e proibiu a instituição de novas fundações que não tivessem os requisitos estabelecidos na legislação pertinente a fundações - ao lado de uma tendência publicista do estadual, evidenciada na proliferação de entidades definidas nas respectivas leis de criação como fundações de direito público.

Isso não obstante "o fato de ser o Estado o instituidor nāo altera a essência do instituto que continua a caracterizar-se como patrimônio dotado de personalidade jurídica, não tendo a doutrina logrado elaborar tópicos suficientes para fundamentar a consideração das fundações instituídas pelo poder público como substancialmente diferentes das instituídas pelos particulares"(49).

\section{3 - Fundações criadas por testamento}

Problema dos mais curiosos surge, a respeito, no direito francês, por força do princípio, ali vigorante, de que um patrimônio não pode existir independente de uma pessoa que seja o seu titular. Na França não se admite a existência de um patrimônio sem uma pessoa, física ou jurídica, que lhe sirva de suporte, tese que apresenta sérios inconvenientes, no concernente à criação das fundaçōes.

Como acabamos de expor, tais entidades se criam mediante a destinação de um acervo de bens a determinado fim, como, por exemplo, a instituição ou a manutenção de um hospital. Mas, admitindo-se o princípio jurídico acima refe-

(49) Coelho, Luiz Fernando, o.c., pág. 15. 
rido, esse acervo de bens não constitui um patrimônio pelo simples fato de ter sido afetado a determinado fim. É necessário que o empreendimento receba primeiro a personalidade, já que somente então poderá ser titular como toda pessoa física ou jurídica, de um patrimônio, que o fundador, ou instituidor, acrescerá dos bens a ele destinados.

Em conseqüência, se uma pessoa deseja, em vida, fundar na França uma instituição, deve primeiro solicitar que um decreto confira personalidade a essa obra; e, uma vez expedido o ato de reconhecimento, fazer doação à recém-criada entidade dos bens que lhe deseja destinar. É-lhe, contudo, impossível proceder assim por testamento, pois, para receber um legado, a pessoa deve existir no momento do óbito do testador. E a jurisprudência dos tribunais civis considera que o legado feito a uma obra ainda não dotada de personalidade é nulo. Para contornar a dificuldade e salvar numerosas fundações, os tribunais administrativos, valendo-se da ficção da retroatividade, fazem remontar os efeitos do decreto ao dia da morte do testador, o que lhes tem permitido validar inúmeros legados. Se não há herdeiros para reclamar, a coisa passa tranqüilamente. É freqüente, porém, os herdeiros pleitearem perante os tribunais judiciários a nulidade de tais legados. E, quando isto ocorre, em geral, obtém ganho de causa, porque esses tribunais, presos, em matéria de sucessão, às regras do Código Civil, consideram impossível contorná-las, através da ficção da retroatividade.

Para tornar a doação estreme de dúvidas, a prática encontrou o meio de elidir o princípio da inexistência de patrimônio sem titular. Assim, o testador que pretende criar uma fundação e esbarra no problema de não ter, ainda, essa entidade personalidade jurídica faz, dos bens destinados ao empreendimento, legado a uma terceira pessoa, encarregada não só de obter o decreto conferindo à obra a necessária personalidade jurídica, mas também de entregar, em seguida, a essa entidade a importância legada. Foi este processo, como se recorda, o utilizado por Edmond Goncourt para a criação da Academia Goncourt, que reveste a forma fundacional e cujo objetivo é auxiliar jovens escritores, distribuindo um prêmio anual de romance. Alphonse Daudet e Hennique foram instituídos seus legatários universais, com o encargo de fundar a Academia. Todo e qualquer hiato foi entāo evitado, graças à interposição dos legatários universais: o patrimônio não ficou jamais sem titular, tendo o Tribunal Civil do Sena e a Corte de Paris reconhecido validade ao procedimento adotado pelo conhecido escritor, que assim ligou seu nome a uma entidade que, através dos anos, continua a atuar, de modo acentuado, na vida literária e intelectual do seu país.

Já no direito brasileiro a situação é diferente, como teve ocasiāo de sustentar Mário Mazagão. Com fundadas razões, insurge-se esse autor contra a doutrina que, inspirada no direito francês, pretende considerar herança ou legado, o estabelecimento de fundação por ato de última vontade, com a destinação de bens para o respectivo patrimônio. 
Reconhece ele que a fundação, ou já existente, ou ainda em embriāo (por ter sido criada por outrem e se achar em via de aperfeiçoamento), pode ser nomeada, por qualquer testador, herdeira ou legatária.

Mas - observa - "quando o próprio testador a institui ${ }_{2}$ destinando-lhe bens livres, tal destinação não constitui herança, nem legado. E ato jurídico de outra espécie, a saber, dotação".

$\mathrm{E}$, a seguir, salientando as diferenças que distinguem visceralmente $\mathrm{o}$ ato criador de fundação do ato que institui herdeiro ou legatário:

"I - A nomeação de herdeiro ou de legatário somente pode ser feita por testamento. Ao contrário, a destinação de bens, constitutiva de fundação, tanto pode ser feita por testamento como por qualquer escritura pública (Código Civil, art. 24).

II - O herdeiro, ou legatário nomeado, recebe o benefício somente quando se abre a sucessão. Ao contrário, a fundação, quando decorrente de ato inter vivos, opera a deslocação dos bens do instituidor durante a vida deste"(50).

\section{IV - AS FUNDAÇŌES NO PROJETO DE CÓDIGO CIVIL}

\section{1 - Fundações dotadas de patrimônio público}

O novo Projeto de Código Civil, projeto de lei no 634-B/75, aprovado pela Câmara dos Deputados em 1984, procura solucionar algumas das controvérsias suscitadas pela lei atual.

Com efeito, dispōe o seu art. 41:

Art. 41- São pessoas jurídicas de direito público interno:

$$
\text { I - A Uniāo. }
$$

II - Os Estados, o Distrito Federal e os territórios.

III - Os Municípios.

IV - As autarquias.

V - As demais entidades de caráter público criadas por lei.

Parágrafo único. Salvo disposiçāo em contrário, as pessoas jurídicas de direito público, a que se tenha dado estrutura de direito privado, regem-se, no que couber, quanto ao seu funcionamento, pelas normas deste Código.

(50) Mazagão, Mário, Fundações criadas por Testamento, in Revista Forense, nº 523, pág. 109. 
Como já nos referíamos no no IV - 2, supra, muita divergência vem suscitando as fundaçōes dotadas de patrimônio público. Os critérios pelos quais se destacam, no direito moderno, as fundaçôes instituídas pelo poder público, são fenômenos acidentais no desenvolvimento histórico da entidade, pois não alteram a essência decorrente da personificação jurídica do patrimônio.

Esta doutrina encontra guarita na opinião de inúmeros jurisconsultos que, no presente como no passado, preocuparam-se com o tema, um dos mais polêmicos da jurisprudência contemporânea, dada a proliferação das fundaçōes em todo o mundo ocidental e a miríade de fundaçōes ditas de direito público, espalhadas pelo País.

Assim, define De Plácido e Silva: "Mas, no direito civil, possui o vocábulo sentido especial e restrito, quando quer designar a instituição que se forma ou se funda pela constituiçāo de um patrimônio ou complexo de bens, para servir a certo fim de utilidade pública, ou em benefício da coletividade. E, assim, se caracteriza a fundação, além dos fins pios ou de benemerência tidos como objeto principal, pelo fato de ocorrer com a sua instituição uma personificação patrimonial, em virtude da qual os bens convertidos para o seu estabelecimento, automatizados, passam a ter uma configuração jurídica, toda própria, independente dos indivíduos ou das pessoas físicas que possam intervir nela" ${ }^{\text {(51). }}$

O Legislador pretende dirimir esta questão, vez por todas, incluindo no capítulo das "Disposiçōes Gerais" do Título II - Das Pessoas Jurídicas - a citada disposição (art. 41, V e $\S$ único) que claramente sujeita as fundações dotadas com patrimônio público, às normas do direito privado.

\section{2 - Fins das Fundaçōes}

No capítulo III do referido Título de Projeto, dispõe o Legislador especificamente sobre as Fundações, in verbis:

Art. 62. Para criar uma fundação, far-lhe-á o seu instituidor, por escritura pública ou testamento, dotaçāo especial de bens livres, especificando o fim a que a destina, e declarando, se quiser, a maneira de administrá-la.

Parảgrafo único. A fundação somente poderá constituir-se para fins religiosos, morais, culturais ou de assistência.

Art. 63. Quando insuficientes para constituir a fundação, os bens a ela destinados serão, se outra coisa não dispuser o instituidor, incorporados em outra fundação, que se proponha a fim igual ou semelhante.

(51) De Plácido e Silva, Fundação in Vocabulário Jurídico, Rio de Janeiro, Forense, 1963. 
Art. 64. Constituída a fundação por negócio jurídico entre vivos, o instituidor é obrigado a transferir-lhe a propriedade, ou outro direito real, sobre os bens dotados, e, se não o fizer, serão transcritos, ou inscritos, em nome dela, por mandado judicial.

Art. 65. Aqueles a quem o instituidor cometer a aplicação do patrimônio, em tendo ciência do encargo, formularāo desde logo, de acordo com as suas bases (art. 62), os estatutos da fundação projetada, submetendo-os, em seguida, à aprovação da autoridade competente, com recurso ao juiz.

Parágrago único. Se não elaborarem os estatutos no prazo assinado pelo instituidor, ou, não havendo prazo, dentro de seis meses, caberá ao Ministério Público fazê-lo. situadas.

Art. 66. Velará pelas fundações o Ministério Público do Estado, onde

'Parágrafo único. Se funcionarem no Distrito Federal, ou em Território, ou, ainda, se estenderem a sua atividade a mais de um Estado, caberá ao Ministério Público Federal esse encargo.

Art. 67. Para que se possam alterar os estatutos da fundação é mister que a reforma:

I - Seja deliberada por dois terços dos componentes para gerir e representar a fundação.

II - Não constrarie ou desvirtue o fim desta.

III - Seja aprovada pelo órgão do Ministério Público, e, caso este a denegue, poderá o juiz supri-la a requerimento do interessado.

Art. 68. Quando a alteração não houver sido aprovada por votação unânime, os administradores da fundação, ao submeterem os estatutos ao órgão do Ministério Público, requererão que se dê ciência à minoria vencida para impugná-la, se quiser, dentro em dez dias.

Art. 69. Tornando-se ilícita, impossível ou inútil a finalidade a que visa a fundação, ou vencido o prazo de sua existência, o órgão do Ministério Público, o qualquer interessado, lhe promoverá a extinção, incorporando-se o seu patrimônio, salvo disposição em contrário no ato constitutivo, ou nos estatutos, em outra fundação, designada pelo juiz, que se proponha a fim igual ou semelhante. 
Das diferenças que o Projeto apresenta com relação ao Código Civil em vigor, gostaríamos de destacar somente a que se refere aos fins das Fundaçōes. Enquanto este não limita o fim a que se pode destinar uma fundaçāo (art. 24), aquele viu por bem restringi-lo aos fins "religiosos, morais, culturais ou de assistência" (art. 62, § único).

Embora na distinção por nós citada ( $\mathrm{n}^{\mathrm{o}}$ - III-4 supra), Lacerda de Almeida refira-se a fim de "utilidade pública", nada impede - pela lei atual - que se criem fundações com fins particulares.

Os códigos civis mais modernos e as leis que regulam as matérias das fundações também não restringem os fins lícitos a prosseguir aos considerados de utilidade pública, deixando, quando muito, nos casos da personalidade depender de ato legislativo ou administrativo, à autoridade competente o cuidado de verificar se o interesse é digno de proteção.

Parece, pois, não restarem dúvidas que nas fundações podem distinguirse, nos fins principais susceptíveis de ser visados pelos instituidores (considerando o problema no plano puramente doutrinário), fins de utilidade pública e fins de utilidade particular, consoante se trate de promover a realização de um fim ideal de interesse geral e de beneficiar a generalidade das pessoas interessadas no objeto da instituição, indiscriminadamente, ou algum interesse, mesmo moral, ligado ao instituidor ou a pessoa ou pessoas por este determinadas. Segundo ensinamento de Marcello Caetano, as fundaçōes de utilidade particular exprimem o desejo do proprietário dos bens afetados de prolongar pelos séculos afora o seu direito de domínio exclusivo, ao contrário das de utilidade pública em que os bens, embora regidos pela vontade do instituidor, passam ao regime de propriedade coletiva, como adiante mostraremos. Parece, por isso, que essas fundações, quando permitidas; deveriam ser sempre temporárias, com o limite máximo da duração média duma geração ( 50 a 60 anos), não só para as aproximar da disciplina das substituições fideicomissárias, como para evitar os inconvenientes práticos da multiplicação dos descendentes beneficiários ao cabo de duas ou três gerações.

Pode inclusive uma fundação de utilidade pública ter encargos de utilidade particular, como quando o fundador se reserva em vida o usufruto de alguns dos bens afetados ou uma pensão a distrair dos respectivos rendimentos, ou quando impõe o pagamento de pensão aos seus herdeiros ${ }^{(52)}$.

Data venia, afastando-nos da defesa em contrário inserida na opinião do ilustre professor lusitano, parece-nos acertada a proposta do Código projetado. É de mister que, com vistas - entre outros motivos - a distinguir melhor as fun-

(52) Cfr. Caetano, Marcello, o.c., pág. 20-25. 
daçōes das associaçōes, e, seguindo o rasto de raciocínio de Lacerda de Almeida, aquelas abstenham-se de perseguir objetivos particulares e sejam admitidas somente para fins de utilidade pública lato sensu - religiosos, morais, etc. como muito bem propugnam o novo Código.

\section{V - BIBLIOGRAFIA}

ALVIM, Agostinho, Comentário ao Código Civil, vol. I, Editora Jurídica e Universitária, Rio de Janeiro, 1968.

BEVILÁQUA, Clóvis, Teoria Geral do Direito Civil, Francisco Alves, Rio de Janeiro, $7^{\text {a }}$ ed., 1955.

Em defesa do Projeto de Código Civil Brasileiro, Francisco Alves, Rio de Janeiro, 1906. 1936.

Código civil comentado, Francisco Alves, Rio de Janeiro, 5 ed.,

CAETANO, Marcello, Das Fundaçōes, Ed. Ática, Lisboa, 3ª d.

CAVALCANTI, T.B. Tratado de direito administrativo, vol. III, 5ª ed.

CHAVES, Antonio, Lições de Direito Civil, Parte Geral, vol. IV, José Bushatsky, São Paulo, 1974.

COELHO, Luiz Femando, Fundações Públicas, 1aㅡ ed., Ed. Forense, Rio de Janeiro, 1978.

CORREA DE OLIVEIRA, José Lamartine, Conceito de pessoa jurídica, Curitiba, 1962.

DE PLÁCIDO E SILVA, Fundação, in Vocabulário Jurídico, Rio de Janeiro, Ed. Forense, 1963.

FERRARA, Francesco, Teoria de las personas jurídicas, Trad. Eduardo Ovejero y Mauri, Ed. Reus, 1929.

FRANCO SOBRINHO, Manuel de Oliveira, Fundações e empresas públicas, Ed. Revista dos Tribunais, São Paulo, 1968.

FRANCO SOBRINHO, Manuel de Oliveira, As fundações e o direito administrativo, in "Revista de Direito Administrativo da Fundação Getúlio Vargas", 100. 
GOMES, Orlando, Introdução ao Direito Civil, Ed. Forense, Rio de Janeiro, 1975.

GONÇALVES, Luiz Cunha, Tratado de direito civil, vol. I, $2^{\text {a }}$ ed., Ed. Max Limonad, São Paulo.

GUIMARĀES, H., As pessoas jurídicas como situações patrimoniais in "Revista Forense", 91(471): 299-310, 1942.

GUSMÃO, Sady Cardoso de, Fundação in "Repertório Enciclopédico do Direito Brasileiro", vol. XXIII, Editor Borsoi, Rio de Janeiro, s.d.

JHERING, R., O espírito do direito romano. Trad. Rafael Bemainon, Ed. Alba, Rio de Janeiro, 1943.

LACERDA, de Almeida, Das Pessoas Jurídicas, Revista dos Tribunais, 1905.

MAZAGĀO, Mário, Fundaçōes criadas por testamento, in "Revista Forense”, no 523, pág. 109.

MONTEIRO, Washington B., Curso de direito civil, vol. I, Ed. Saraiva, São Paulo, 1964.

NÓBREGA, Vandick L., História e sistema do direito privado romano, Freitas Bastos, 3ㄹ ed., Rio de Janeiro.

PONTES, de Miranda, Tratado de direito privado, Parte Geral, vol. I, Editor Borsoi, Rio de Janeiro, 1954.

RÁO, Vicente, $\mathrm{O}$ direito e a vida dos direitos, vol. II, Ed. Max Limonad, São Paulo, s.d.

RODRIGUES, Silvio, Direito Civil, Parte Geral, vol. I, Ed. Saraiva, 5- ed., São Paulo, 1974.

SENNA, Homero; MONTEIRO, Clóvis Z., Fundaçōes no Direito na Administraçāo, Instituto de Documentação da Fundação Getúlio Vargas, Rio de Janeiro, $1^{\text {a }}$ ed., 1970.

SERPA LOPES, Miguel Maria, Curso de direito civil, vol. I, 1937.

SILVA PEREIRA, Caio Mário, Instituiçōes de Direito Civil, vol. I, Ed. Forense, Rio de Janeiro, 1966, 2ª ed. 